\title{
USING PROJECT-BASED LEARNING TO IMPROVE STUDENTS' WRITING ON GREETING CARD
}

\author{
Yudha Pambudi Wibowo, Kresna Rahma Aji \\ yudhawibowo65@gmail.com, petapabesi@gmail.com \\ SMP N 2 Karanganyar, Kabupaten Pekalongan, Program Pascasarjana UNNES
}

\begin{abstract}
English is a compulsory subject in junior high school. One of English skills is writing which is one of learning outcomes. However, students' writing ability on greeting card was still below the passing grade. It was because of low students' creativity in writing, low students' vocabulary, low comprehension in making greeting card, and teacher had not implemented suitable learning method in the English instruction. This research focused on the implementation of project based learning as a learning method in writing on greeting card. Project-based learning is a systematic learning method that gives opportunity to students to do project as a medium to achieve learning goals. The research used several methods of data collecting. They are questionnaire, observation, and test. The result showed improvement of students writing on greeting card through project-based learning method. Those improvements can be seen from the increasing of the students' creativity in writing greeting card as an improvement of learning process and students learning result.
\end{abstract}

Keywords : writing, greeting card, project-based learning.

\section{INTRODUCTION}

English is absolutely needed in junior high school. It is one of subjects evaluated in national examination in junior high school. Related with the curriculum, the curriculum used in the researcher's school is 2013 curriculum. This curriculum applies students' competence with the authentic assessment. It has competence standard that emphasizes on totality competences of 3 elements, namely affective, knowledge, and psychomotor.

In the real situation, there are so many students who are not creative in responding the learning process. They seem to be passive in English instruction, less creative and sometimes they neglect their tasks. Moreover, if they face writing assignment there are some emerging problems in writing skill; low level vocabulary related with the topic, the use of part of speech, students are not able to make a meaningful sentence. Students find difficulties in developing a text because they do not know well the generic structure of the text.

Based on the problems, the researchers try to use a proper learning method to enhance students' creativity, so that it can enhance students' writing on greeting card. The researchers hope that students will be good in writing greeting card and students will be more creative in writing. Researcher looked for suitable learning method to overcome some problems above. Based on the context, and faced problems by students of IX A, SMP N 2 Karanganyar, the researchers applied project-based learning. 


\section{LITERATURE REVIEW}

Writing is one of competence of mastering English as idefined by many experts. According to Urquhart and McIver (2005) "Writing is a process of exploration that offers benefits to students and content are teachers alike. As students write to make their ideas and comprehensible, they experience the fun of discovery, and so do their teachers". According to Olson (2009) "Writing is nothing more than thought on paper-considered, organized thought". Based on the definitions above, it can be understood that writing is an English skill in expressing written thought on a piece of paper obeying grammar and punctuation.

\section{Kinds of Writing Skill}

Suyanto (2007) argues that writing in general can be divided into four parts as follow: 1 . Copying. 2. Guided Writing. 3. Substitution Writing, and 4. Free Writing.

\section{The Nature of Greeting Card}

According to Yuliani and Arini (2011: 110) "Greeting card is a card to express friendship or other expression." Lestari et. al. define (2014:8) "Greeting card is card to express someone feeling. "A greeting card is an illustrated,folded card featuring and expression of friendship or other sentiment. According to definitions above, it can be concluded that greeting card isa card to express someone's feeling to others using interesting pictures.

\section{Kinds of Greeting Card}

Lestari, et al. (2014) states kinds of greeting card are as follows:

1. Congratulation Card. 2.Thank You Card. 3. Birthday Card, and 4. Get Well Card.

\section{The Nature of Project-Based Learning}

Markham (2011) defines "Project-based learning integrate learning and doing. Students learn knowledge and elements of the core curriculum, but also apply what they know to solve authentic problems and produce results that matter. "While according to Ferrara (2012) "Project- based learning is a systemic teaching method that engages students in learning essential knowledge and skills through an extended, students influenced inquiry process structured around complex, authentic questions and carefully designed tasks and products. "According to the definitions above, it can be concluded that project-based learning is a systematic learning method that gives opportunity to students to do project as a medium to achieve learning goals.

\section{The Characteristic of Project-Based Learning}

Stivers (2010) argues project-based learning varies from classroom, but it is often characterized by the following procedures :1. Organized around a problem or challenge without a predetermined solution. 2.Creates a need to know of essential content and skills.3. Students design the process for reaching a solution. 4.Requires critical thinking, problem solving, collaboration, and various forms of communication. 5. Provides the opportunity for students to examine the task from differentperspective using variety of resources, separate relevant form irrelevant information, and manage the information they gather. 6 . Students regularly reflect on what they are doing. 7.A final product is produced and is evaluated for quality. 8.The classroom has an athmosphere that tolerates error and change. 9. The teacher takes on the role of a facilitator rather than leader. 


\section{The Benefit of Project-Based Learning}

Larmer, (2015) says that project based learning is a powerful teaching method that does the following : 1. Motivates students. 2. Prepares students for college, careers, and citizenship. 3.Helps students meet standards and do well on tests that askstudents to demonstrate in-depth knowledge and thinking skills. 4. Allows teachers to teach in a more satisfying way. 5. Provides schools and districts with new ways to communicate and to connect with parents, communities, and the wider world.

\section{Steps in Project-Based Learning}

According BPDMPK and PMP (2014) steps in project based learning are as follow: 1. Determine basic question. Learning begins by essential questions that elicit students to do activities. 2. Design project planning. Planning is done collaboratively between teacher and students. Thus, students are expected to possess the project. 3. Arrange the Schedule. Teacher and students collaboratively arrange schedule activity in doing project. 4. Supervise Students and Project Advancement. Teacher is responsible to supervise students' project. Supervision is done by facilitating students in every process. 5. Examine the Result. Evaluation is done to help teacher to assess the standard, to evaluate the students progress, to give feedback about students' comprehension, to help teacher to arrange next leaning strategy. 6.Evaluate Students' Experience. At the end of the learning, teacher, and students reflect activities and projects. Reflection process is done individually and collectively.

\section{METHOD}

Setting of Research

The researcher try to overcome the problem by applying project based learning method. The researchers planned the instruction on lesson plan, arranged instrument required. This research involved students actively in learning process. The passing grade of students in writing on greeting card is 75.The researchers used observation, photo, and recording of students' interaction.

\section{Location and Subject of Research}

This is a practical research. It is based on real problem in language instruction in SMP N 2 Karanganyar of Pekalongan Regency, in the first semester in academic year 2016/2017. The subject of the study is all of IX A students. There are 22 students consist of 14 boys, and 8 girls.

\section{Object of Research}

The objects of this research are as follow: 1 . Students do not know about the generic structure of greeting card, 2. Students find difficulties in developing a sentence to be a paragraph, and 3 . Student are not able to make a greeting card creatively.

\section{Indicator of Success in This Study}

This research will be successful if :1.Minimally there are $85 \%$ of students can pass the passing grade as 75. 2.There is enhancement in students attitude.3.There is enhancement in students' writing on greeting card. 


\section{Data Resources}

The data resources in this research comes from students test and observation result. Teacher observe students attitude and creativity in writing on greeting card.

\section{Time of the Research}

This research took a month. It was on a November $17^{\text {th }} 2016$ to November $28^{\text {th }} 2016$.

\section{Technique of Data Collecting}

This research has 2 variables. Dependent variable namely students' writing on greeting card and independent variable namely project based learning method. Technique of collecting data in this research is by using 2 instruments as follows:1. Test Instrument. Test is conducted to measure students comprehension on greeting card. Aspect graded in this test is students knowledge on greeting card. 2. Non Test Instrument. This study uses observation and questionnaire. Observation. Researcher observes students creativity in writing on greeting card, students attitude, students skill in creating greeting card. b. Questionnaire. The questionnaire is used to measure students mastery in greeting card, and their creativity in creating greeting card.3. Validity. The test instrument is validated through content validity by adjusting the aspects graded to the theory and it's basic competence. Surface validity is used by consulting to researcher's colleague e. Having consulted, the instruments are proper to get data. Then researcher use time triangulation while collecting the data.

\section{Research Procedure}

Researcher made a lesson plan, observation sheet, test, and questionnaire. Then, he applied project based learning in his teaching. Lesson plan was performed in three meetings. Two hours in the first meeting, two hours in the second meeting, and two hours in the third meeting. He also observed the students interaction and students behaviour. In the first meeting, he divided the classroom into 5 groups, then he applied lesson plan in the first meeting. Then in the second meeting he asked the participation of students to discuss the questions with their homegroup, got additional information from other group and back to their homegroup. Finally in the third meeting, students made a greeting card with their group, took te test of greeting card individually. Students also answered the questionnaire outside of the class.

\section{FINDINGS AND DISCUSSION}

\section{Findings}

According to the data, there were only 11 students or $50 \%$ who have completed the passing grade. The average score in the class was 71.36 or 2.85 with predicate $\mathrm{B}+$. This belongs to low score. Then researcher tried to apply project based learning method and observe students' attitude. The results of the study are as follow. 
The $2^{\text {nd }}$ TEYLIN International Conference Proceedings

April 2017

Table 1. Attitude in Learning Writing on Greeting Card of the Students of IX A SMP N 2 Karanganyar Pekalongan

\begin{tabular}{|l|l|l|l|l|}
\hline \multirow{2}{*}{ No. } & \multirow{2}{*}{ Name } & \multicolumn{3}{l}{ Score } \\
\cline { 3 - 5 } & & Score & $1-4$ & Predicate \\
\hline 1 & AAS & 88 & 3,52 & Good \\
\hline 2 & AS & 88 & 3,52 & Good \\
\hline 3 & AI & 88 & 3,52 & Good \\
\hline 4 & ANF & 100 & 4 & VG \\
\hline 5 & AH & 100 & 4 & VG \\
\hline 6 & AP & 100 & 4 & VG \\
\hline 7 & BA & 88 & 3,52 & Good \\
\hline 8 & DAR & 88 & 3,52 & Good \\
\hline 9 & ER & 100 & 4 & VG \\
\hline 10 & FMF & 88 & 3,52 & Good \\
\hline 11 & HS & 100 & 4 & VG \\
\hline 12 & MRS & 100 & 4 & VG \\
\hline 13 & MSB & 88 & 3,52 & Good \\
\hline 14 & NU & 75 & 3 & Good \\
\hline 15 & RA & 100 & 4 & VG \\
\hline 16 & RM & 75 & 3 & Good \\
\hline 17 & SNA & 88 & 3,52 & Good \\
\hline 18 & TAR & 100 & 4 & VG \\
\hline 19 & TAU & 75 & 3 & Good \\
\hline 20 & UMS & 88 & 3,52 & Good \\
\hline 21 & ZA & 88 & 3,52 & Good \\
\hline 22 & AF & 88 & 3,52 & Good \\
\hline MEAN & 90,59 & 3,62 & Good \\
\hline MAXIMUM & 100 & 4,00 & VG \\
\hline MINIMUM & 75 & 3,00 & Good \\
\hline & & & & \\
\hline
\end{tabular}

Generally students attitude were good and very good. It can be seen from the table 1 . Mean score was 90.59 or 3.62 with predicate good. The highest score was 100 or 4.00 with predicate very good. And the lowest was 75 or 3.00 with predicate good.

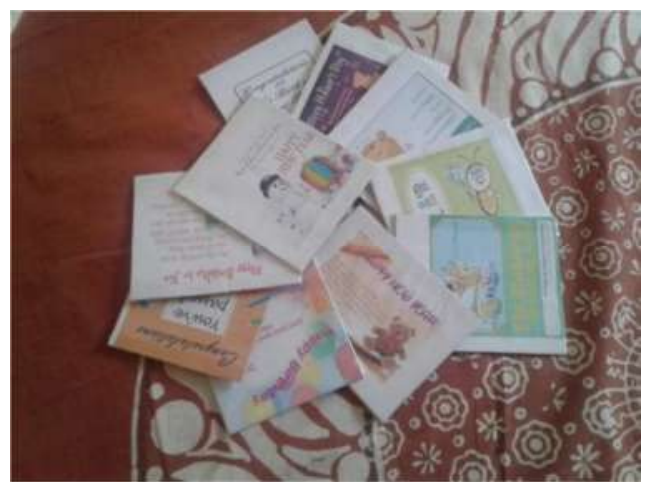

Figure 1. Learning Media of Greeting Card

Then the writer use media as learning aid in project based learning. There were some examples of greeting card as shown by figure 1 above. 


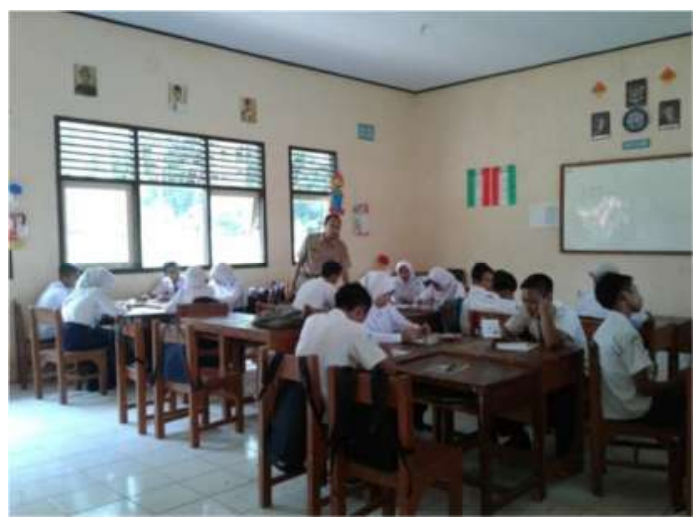

Figure 2. Students worked in a group.

Teachers divided students into 5 groups. Students in each group are given task to be discussed. While students were discussing and working together with group members. Teachers worked as observer to observe students creativity, and students attitudes based on the observation sheet.

Then, based on the observation sheet. The reseaercher gained the data of creativity on greeting card that scored according to the rubric. The data as shown by Table 2 .

Table 2. Creativity in Writing on Greeting Card of the Students of IX A SMP N 2 Karanganyar Pekalongan

\begin{tabular}{|c|c|c|c|c|}
\hline \multirow{2}{*}{ No. } & \multirow{2}{*}{ Name } & \multicolumn{3}{|l|}{ Score } \\
\hline & & Score & $1-4$ & Predicate \\
\hline 1 & AAS & 85 & 3,40 & $\mathrm{~B}+$ \\
\hline 2 & AS & 75 & 3,00 & $\mathrm{~B}+$ \\
\hline 3 & AI & 80 & 3,20 & $\mathrm{~B}+$ \\
\hline 4 & ANF & 80 & 3,20 & $\mathrm{~B}+$ \\
\hline 5 & $\mathrm{AH}$ & 90 & 3,60 & A- \\
\hline 6 & AP & 90 & 3,60 & A- \\
\hline 7 & BA & 75 & 3,00 & $\mathrm{~B}+$ \\
\hline 8 & DAR & 75 & 3,00 & $\mathrm{~B}+$ \\
\hline 9 & ER & 95 & 3,80 & A- \\
\hline 10 & FMF & 80 & 3,20 & $\mathrm{~B}+$ \\
\hline 11 & HS & 80 & 3,20 & $\mathrm{~B}+$ \\
\hline 12 & MRS & 85 & 3,40 & $\mathrm{~B}+$ \\
\hline 13 & MSB & 75 & 3,00 & $\mathrm{~B}+$ \\
\hline 14 & $\mathrm{NU}$ & 75 & 3,00 & $\mathrm{~B}+$ \\
\hline 15 & RA & 95 & 3,80 & A- \\
\hline 16 & RM & 75 & 3,00 & $\mathrm{~B}+$ \\
\hline 17 & SNA & 85 & 3,40 & $\mathrm{~B}+$ \\
\hline 18 & TAR & 85 & 3,40 & $\mathrm{~B}+$ \\
\hline 19 & TAU & 75 & 3,00 & $\mathrm{~B}+$ \\
\hline 20 & UMS & 75 & 3,00 & $\mathrm{~B}+$ \\
\hline 21 & $\mathrm{ZA}$ & 75 & 3,00 & $\mathrm{~B}+$ \\
\hline 22 & $\mathrm{AF}$ & 75 & 3,00 & $\mathrm{~B}+$ \\
\hline \multicolumn{2}{|c|}{ MEAN } & 81 & 3,24 & $\mathrm{~B}+$ \\
\hline \multicolumn{2}{|c|}{ MAXIMUM } & 95 & 3,80 & A- \\
\hline \multicolumn{2}{|c|}{ MINIMUM } & 75 & 3,00 & $\mathrm{~B}+$ \\
\hline
\end{tabular}


The students' creativity were measured from 5 parameters in the rubric. Those parameters are: Student use dictionary to make a greeting card. Student's competence to make sentences in greeting card. Student works actively in his/ her group. Student designs greeting card creatively. Student makes a conclusion about greeting card actively. The mean of score of students' creativity in writing on greeting card was 81 or 3.24 with predicate $\mathrm{B}+$. The maximum score was 95 or 3.8 with predicate A-, and the lowest score was 75 or 3 with predicate $\mathrm{B}+$. The students activity in their group illustrated vy figure 3 below.

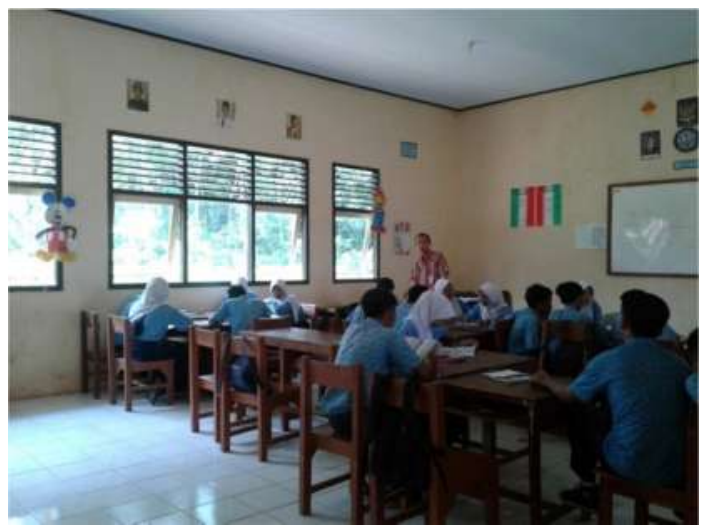

Figure 3 Students work creatively in their group

Then according to the lesson plan, students worked in their group to make greeting card. They determine the topic of greeting card by their own group. Then prepare, formulate, and make it. The teacher evaluated workgroups from 8 aspects. The evaluation of students workgroup are based on rubric. The students worgroup are illustrated in figure 4 below.

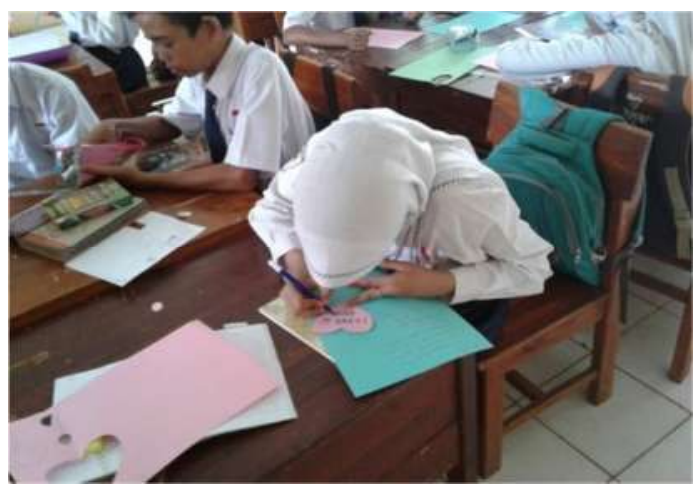

Figure 4. Students were doing project of making greeting card

Students were evaluated based on instrument of project based learning. It was a project evaluation. Teacher obtained test score of workgroup. The score illustrated by Table 3. Then, students also got score of students writing on greeting card. Teacher did not only grade the product of greeting card, but it was a project evaluation. The workgroup score of writing on greeting card is shown by the following Table 3. 
Table 3. Workgroup Score of Writing On Greeting Card of the Students of IX A SMP N 2 Karanganyar Pekalongan

\begin{tabular}{|c|c|c|c|c|c|c|c|}
\hline \multirow{2}{*}{ No. } & \multirow{2}{*}{ Group Name } & \multicolumn{3}{|c|}{ Test Score } & \multicolumn{3}{|c|}{ Project Score } \\
\hline & & Score & $1-4$ & Predicate & Score & $1-4$ & Predicate \\
\hline 1 & Grape & 100 & 4 & A & 90 & 3,6 & A- \\
\hline 2 & Shark & 100 & 4 & A & 98 & 3,9 & A \\
\hline 3 & Cat & 100 & 4 & A & 85 & 3,4 & $\mathrm{~B}+$ \\
\hline 4 & Scorpion & 100 & 4 & A & 92 & 3,7 & A- \\
\hline 5 & Owl & 100 & 4 & A & 88 & 3,5 & $\mathrm{~B}+$ \\
\hline \multicolumn{2}{|c|}{ MEAN } & 100 & 4 & A & 91 & 3,6 & A- \\
\hline \multicolumn{2}{|c|}{ MAXIMUM } & 100 & 4 & A & 98 & 3,9 & A \\
\hline \multicolumn{2}{|c|}{ MINIMUM } & 100 & 4 & A & 85 & 3,4 & $\mathrm{~B}+$ \\
\hline
\end{tabular}

It shows the highest score of workgroup score was 100 , the lowest was 100 , and the mean score was 100 or 4 with predicate A.The highest score on students project on making greeting card was 98 or 3.9 with predicate $\mathrm{A}$, the lowest score was 85 or 3.4 with predicate $\mathrm{B}+$, and the mean of students score on making greeting card was 91 or 3.6 with predicate A-.Then the product of students writing on greeting card is shown by figure 5 below

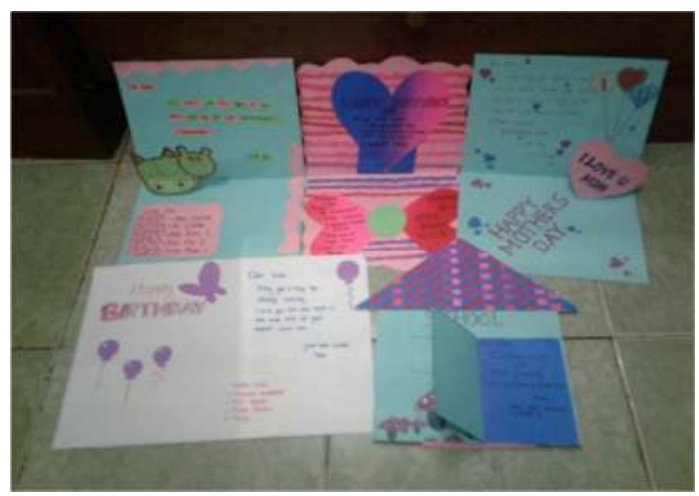

Figure 5. Students' greeting card.

Then students were given questionnaire. Students' questionnaire of self assessment was given after the lesson. And the result is shown by table 4 below.

Table 4.

Table 4. Questionnaire Score of Self Assessment on Writing on Greeting Card of the Students of IX A of SMP N 2 Karanganyar Pekalongan in First Semester of Academic Year 2016/ 2017

\begin{tabular}{|l|l|l|l|l|}
\hline \multirow{2}{*}{ No. } & \multirow{2}{*}{ Name } & \multicolumn{3}{l|}{ Score } \\
\cline { 3 - 5 } & & Score & $1-4$ & Predicate \\
\hline 1 & AAS & 81 & 3,24 & B+ \\
\hline 2 & AS & 84 & 3,36 & B+ \\
\hline 3 & AI & 84 & 3,36 & B+ \\
\hline 4 & ANF & 88 & 3,52 & A- \\
\hline 5 & AH & 88 & 3,52 & A- \\
\hline 6 & AP & 88 & 3,52 & A- \\
\hline
\end{tabular}




\begin{tabular}{|l|l|l|l|l|}
7 & BA & 84 & 3,36 & B + \\
\hline 8 & DAR & 90 & 3,60 & A- \\
\hline 9 & ER & 90 & 3,60 & A- \\
\hline 10 & FMF & 84 & 3,36 & B+ \\
\hline 11 & HS & 81 & 3,24 & B+ \\
\hline 12 & MRS & 88 & 3,52 & A- \\
\hline 13 & MSB & 90 & 3,60 & A- \\
\hline 14 & NU & 88 & 3,52 & A- \\
\hline 15 & RA & 88 & 3,52 & A- \\
\hline 16 & RM & 90 & 3,60 & A- \\
\hline 17 & SNA & 94 & 3,76 & A- \\
\hline 18 & TAR & 84 & 3,36 & B+ \\
\hline 19 & TAU & 84 & 3,36 & B+ \\
\hline 20 & UMS & 78 & 3,12 & B+ \\
\hline 21 & ZA & 84 & 3,36 & B+ \\
\hline 22 & AF & 84 & 3,36 & B+ \\
\hline MEAN & 86 & 3,44 & B+ \\
\hline MAXIMUM & 94 & 3,76 & A- \\
\hline MINIMUM & 78 & 3,12 & B+ \\
\hline
\end{tabular}

Table 4 above shows the mean was 86 or 3.44 with predicate $\mathrm{B}+$. The maximum obtained score was 94 or 3,76 with predicate A-, and the lowest was 78 or 3.12 with predicate B+. Generally, the result is good. So, it can be concluded that students have comprehended makin greeting card.

\section{DISCUSSION}

Tabel 5. Test Scores of Writing on Greeting Card of the Students of IX A SMP N 2 Karanganyar

\begin{tabular}{|l|l|l|l|l|l|l|l|}
\hline \multirow{2}{*}{ No. } & \multirow{2}{*}{ Name } & \multicolumn{3}{|l|}{ Pre Test } & \multicolumn{3}{l|}{ Post Test } \\
\cline { 3 - 9 } & & Score & $1-4$ & Pred. & Score & $1-4$ & Pred. \\
\hline 1 & AAS & 100 & 4 & A & 100 & 4 & A \\
\hline 2 & AS & 60 & 2,4 & C + & 100 & 4 & A \\
\hline 3 & AI & 60 & 2,4 & C+ & 80 & 3,2 & B+ \\
\hline 4 & ANF & 80 & 3,2 & B+ & 90 & 3,6 & A- \\
\hline 5 & AH & 80 & 3,2 & B+ & 100 & 4 & A \\
\hline 6 & AP & 80 & 3,2 & B+ & 100 & 4 & A \\
\hline 7 & BA & 80 & 3,2 & B+ & 90 & 3,6 & A- \\
\hline 8 & DAR & 40 & 1,6 & C- & 100 & 4 & A \\
\hline 9 & ER & 100 & 4 & A & 100 & 4 & A \\
\hline 10 & FMF & 80 & 3,2 & B+ & 100 & 4 & A \\
\hline 11 & HS & 80 & 3,2 & B+ & 80 & 3,2 & B+ \\
\hline 12 & MRS & 90 & 3,6 & A- & 100 & 4 & A \\
\hline
\end{tabular}




\begin{tabular}{|l|l|l|l|l|l|l|l|}
13 & MSB & 40 & 1,6 & $\mathrm{C}-$ & 100 & 4 & $\mathrm{~A}$ \\
\hline 14 & NU & 60 & 2,4 & $\mathrm{C}+$ & 80 & 3,2 & $\mathrm{~B}+$ \\
\hline 15 & RA & 100 & 4 & $\mathrm{~A}$ & 100 & 4 & $\mathrm{~A}$ \\
\hline 16 & RM & 60 & 2,4 & $\mathrm{C}+$ & 80 & 3,2 & $\mathrm{~B}+$ \\
\hline 17 & SNA & 60 & 2,4 & $\mathrm{C}+$ & 80 & 3,2 & $\mathrm{~B}+$ \\
\hline 18 & TAR & 60 & 2,4 & $\mathrm{C}+$ & 100 & 4 & $\mathrm{~A}$ \\
\hline 19 & TAU & 80 & 3,2 & $\mathrm{~B}+$ & 80 & 3,2 & $\mathrm{~B}+$ \\
\hline 20 & UMS & 60 & 2,4 & $\mathrm{C}+$ & 100 & 4 & $\mathrm{~A}$ \\
\hline 21 & ZA & 60 & 2,4 & $\mathrm{C}+$ & 100 & 4 & $\mathrm{~A}$ \\
\hline 22 & AF & 60 & 2,4 & $\mathrm{C}+$ & 80 & 3,2 & $\mathrm{~B}+$ \\
\hline MEAN & 71 & 2,85 & $\mathrm{~B}+$ & 93 & 3,71 & $\mathrm{~A}-$ \\
\hline MAXIMUM & 100 & 4 & $\mathrm{~A}$ & 100 & 4 & $\mathrm{~A}$ \\
\hline \multicolumn{2}{|l|}{ MINIMUM } & 40 & 1,6 & $\mathrm{C}-$ & 80 & 3,2 & $\mathrm{~B}+$ \\
\hline
\end{tabular}

Table 5 above shows students individual test in writing on greeting card. The data consist of pre test and post test score. The post test score generally were better than the pre test score. It indicates that project based learning gave positive impact on students' writing on greeting card. The pre test was the condition before students thought using project based learning method. The mean score of the pre test was 71 or 2.85 withn predicate $\mathrm{B}+$, the maximum of pre test score was 100 or 4 with predicate A, and the minimum of pre test score was 40 or 1.6 with predicate C-. There were 11 students or $50 \%$ failed to pass students' passing grade as 75 . Post test score was score assessed after students taking project based learning method. There were 22 students or $100 \%$ of students who passed the passing grade of greeting card. The mean of post test score was 93 or 3.71 with predicate $A-$, the maximum score was 100 or 4 with predicate $A$, the lowest score was 80 or 3.2 with predicate $\mathrm{B}+$. The students who passed the passing grade in the post test were more than $85 \%$. It indicates that learning process was successful.

\section{CONCLUSION AND SUGGESTIONS}

\section{Conclusion}

According to the analysis and discussion of this research, the researcher concludes as follow. There is improvement on IX A students of SMP N 2 Karanganyar in writing on greeting card. The mean of pretest score of IX A students as 71,36 or 2,85 with predicate $\mathrm{B}+$. This score is below the passing grade of English as 75 . There were 11 students or $50 \%$ of students having scores lower than passing grade in pretest. The lowest score was 40 or 1.6 with predicate C-, and the highest score was 100 or 4 with predicate A.

Then the researcher applied proect based learning method. And 22 students were tested individually afterwards. The results of postest shows that there were 22 students passed the passing grade. The mean of score was 92.73 or 3.71 with predicate A-. The lowest score was 80 or 3.2 with predicate $\mathrm{B}+$. There were 22 students or $100 \%$ passed the passing grade. It means that the learning in writing on greeting card was successful. And project based learning method could increase the mean score of students knowledge in writing on greeting card as 21.36 point or 29.94 . 
Based on the observation, it can also be seen that students showed their great attitude in writing on greeting card. They worked cooperatively and responsibly. The students creativity can also be seen from their work on greeting card through project based learning method. Finally, based on the questionnaire result, students could understand and write a greeting card correctly.

\section{Suggestions}

Suggestions based on the conclusion of the finding are as follows :1. Teachers: a. Teachers should make a proper lesson plan before teaching. b.Teachers should be able to use project based learning method because it can increase the teaching and learning process.c.Teachers who want to apply project based learning should design interactive instructiond. Teachers should master materials in order to be more communicative in teaching. 2. School: a. School should provide facilities for learning that suitable with students characterstics. b. School should supports teachers to join teacher association and workshop of learning methods.

\section{REFERENCES}

Bell, Stephanie. (2010). Project-Based Learning for the 21st Century: Skills for the Future. Taylor \& Francis Group, LLC.

BPSDMPK and PMP. (2014). Materi Pelatihan Guru Implementasi Kurikulum 2013. Jakarta:

Kemdikbud.

Burns, Anne. (2010). Doing Action Research.New York: Routledge

Harmer, Nichola and Alison Stokes.(2014). The Benefit and Challenges of Project Based

Learning. Plymouth: Pymouth University

Hidayah, Nur. (2014).Peningkatan Kompetensi Menulis Shopping List dengan Metode

Pembelajaran Berbasis Tugas (Task Based Instruction) pada Peserta Didik Kelas

VII A SMPN 1 Tegal Tahun Pelajaran 2013/ 2014. Penelitian Tindakan Kelas, Tegal.

Hornby, A.S. Oxford Advanced Learner's Dictionary of Current English. Revised and Updated. Oxford: Oxford University Press.

Larmer, John et al.(2015). Setting the Standard for Project Based Learning. Alexandria: ASCD

Lestari, Ruliah, et al. (2014). Pendalaman Materi Sukses Ujian Nasional Bahasa Inggris. Jakarta: AKASIA Citraprima.

Olson, Judith F.(2009). Writing Skills Success in 20 Minutes a Day. New York: LearningExpress, LLC

Riyanto, Yatim. (2010). Metodologi Penelitian Pendidikan. Surabaya: PENERBIT SIC

Stivers, J. (2010). Project-Based Learning. ESPY 505

Suyanto, Kasihani K.E. (2007). English for Young Learners. Jakarta: Bumi Aksara.

The functionaltext.blogspot.com/2011/08/greeting-cards.html accessed November 2016

Thomas, John W. (2007). A Review of Research on Project Based Learning. C California Tredinnick, Mark. (2008). Writing Well. Cambridge: Cambridge University Press.

Urquhart, Vicki and Monette McIver. (2005). Teaching writing in the Content Areas.Alexandria: Association for Supervision Curriculum Development. 